\title{
Review on Training and Development in Human Management
}

Abang Mohd. Razif Abang Muis, Abdul Hair Beddu Asis, Syamsul Azizul Marinsah, Mohd Nur Hidayat Hasbollah Hajimin, Musmuliadi Kamaruding, Mohd Taqwudin Mohd Yazid

To Link this Article: http://dx.doi.org/10.6007/IJARBSS/v11-i5/10024

DOI:10.6007/IJARBSS/v11-i5/10024

Received: 27 March 2021, Revised: 30 April 2021, Accepted: 13 May 2021

Published Online: 29 May 2021

In-Text Citation: (Muis et al., 2021)

To Cite this Article: Muis, A. M. R. A., Asis, A. H. B., Marinsah, S. A., Hajimin, M. N. H. H., Kamaruding, M., \& Yazid, M. T. M. (2021). Review on Training and Development in Human Management. International Journal of Academic Research in Business and Social Sciences, 11(5), 704-716.

Copyright: (C) 2021 The Author(s)

Published by Human Resource Management Academic Research Society (www.hrmars.com) This article is published under the Creative Commons Attribution (CC BY 4.0) license. Anyone may reproduce, distribute, translate and create derivative works of this article (for both commercial and non-commercial purposes), subject to full attribution to the original publication and authors. The full terms of this license may be seen at: http://creativecommons.org/licences/by/4.0/legalcode

Vol. 11, No. 5, 2021, Pg. 704 - 716

Full Terms \& Conditions of access and use can be found at http://hrmars.com/index.php/pages/detail/publication-ethics 




\title{
Review on Training and Development in Human Management
}

\author{
Abang Mohd. Razif Abang Muis, Abdul Hair Beddu Asis, \\ Syamsul Azizul Marinsah, Mohd Nur Hidayat Hasbollah Hajimin \\ Centre for the Promotion of Knowledge and Language Learning Universiti Malaysia Sabah, \\ Sabah, Malaysia \\ Email: amrazif@ums.edu.my, khairasis@ums.edu.my, syamsulazizul@ums.edu.my, \\ mnhidayath_h@ums.edu.my
}

Musmuliadi Kamaruding

Faculty of Engineering Universiti Teknologi Mara, Selangor, Malaysia

Email: musmuliadi@uitm.edu.my

\begin{abstract}
Mohd Taqwudin Mohd Yazid
Centre for the Promotion of Knowledge and Language Learning Universiti Malaysia Sabah, Sabah, Malaysia

Email: mohdtaqwudin@ums.edu.my
\end{abstract}

\begin{abstract}
The purpose of this paper is to help in term of providing a better understanding on training and development in human management amongst the researchers on this field. Training and development should be the important aspect increase the workers potential in the organisations. The lack of training and development will give a negative impact in the organisations such as inefficiency, deviation, misconduct, and bribery act freely amongst workers. The aim of this study is realized by profiling existing literature to understand the determinants of training and development in human management, research trends, theories, and future research opportunities. A comprehensive search was initiated on Google Scholar, Scopus, Emerald Insight, JSTOR, and ProQuest. Final inclusion criteria were systematic reviews on training and development in human management. Articles were screened in three components by the title, abstract and full text. Data was abstracted by identifying general information, outcome, conclusions, and recommendations of each reviewed paper. After cautiously and carefully examining the extant literature and by utilizing these relevant academic-based research databases, a total of 100 papers published in peer-reviewed journals over the last decade were reviewed and analysed using well-established systematic review methodology. In the initial search, 158 potential reviews were identified. After removing same papers, 97 articles were excluded by screening the title or abstract. After a full text review of each article, 47 papers were included in the final synthesis. The adopted
\end{abstract}


systematic review revealed that there are limited contributions in understanding training and development in human management. The review provides several venue for future research including training and development concepts, models, forms, contents, and evaluations aspect at different levels.

Keywords: Training, Development, Human Management, Human Development, Organisation.

\section{Introduction}

The purpose of this systematic review was to identify scholarly reviews published on the training and development in human management; and synthesize research recommendations toward improving the training and development in human management subject. This is the first reported synthesis of research recommendations for studying training and development in human management. Training and development were one of the most important aspect in the human management in the organisations or institutions. Through training and development, workers in the organisation can increase their knowledges, abilities, and skills so they can complete their works efficiently and effectively. Besides that, training and development also playing role as the source of motivation for workers. Commonly, through the consecutively training, workers have a chance to get promoted. As such, employees will be able to enjoy greater benefits and rewards while gaining the respect and respect of top management and other employees within the organization. Training and development are also important organizational activities because of their impact on employee productivity. Orientation and training help new employees become productive workers in the organization and experienced workers can accept changes and job requirements. Development programs give employees the opportunity to grow and advance in their careers whether inside or outside the organization (Kadir, 2009).

Organizational training is an ongoing process of learning designed to change employees' attitudes, knowledge, and skills to improve their work performance. This change in behaviour can contribute to the achievement of organizational goals. Effective training programs can provide benefits and benefits to any organization, employee, or government. However, it may be difficult to determine whether a program is effective or not. The effectiveness of a training program can be evaluated through reaction, learning and decision-making approaches. Human training and development programs are a very difficult and complex activity. These difficulties involve several stages of policy development, training plan development and training program management. Parties involved in human development should form an organizational training policy in line with the vision, philosophy, and objectives of an organization. The success of the training program depends on the level of ability and ability, knowledge, skills, and behaviour of the employee to be applied and applied to enhance the productivity of the employee while at the same time achieving organizational goals. All parties' awareness of the importance of training programs in the promotion of career and employee motivation will encourage organizations either in the private sector or the government to make training programs an investment that brings benefits and benefits to all parties (Aminuddin, 1994).

Training in the organization is an ongoing learning process designed to change the attitudes, improve knowledge, and skills of employees so that their work performance can be improved. These behavioural changes will be able to contribute towards the achievement of an organizational goal. Effective training programs can provide benefits and benefits to either the organization, employees, or the government. However, it is quite difficult to evaluate 
whether a program is effective or not. The effectiveness of a training program can be assessed through reaction, learning and decision approaches. Training and human development programs are a very difficult and complex activity. These difficulties involve several stages of training policy formation, training plan formation and training program management. Those involved in human development should form an organizational training policy that is in line with the vision, philosophy, and objectives of an organization. The actual success of the training program depends on the level of abilities and capabilities, knowledge, skills, and behaviours of employees can be applied and applied to increase employee productivity and at the same time achieve organizational goals. Awareness of all parties on the importance of training programs in career advancement and employee motivation will encourage organizations whether private or government sector to make training programs as an investment that brings benefits and benefits to all parties (Aminuddin, 1994).

In this era of globalization, human beings are pursuing success after success in line with the increasing current of modernization. Therefore, various training and development programs have been implemented and participated so as not to drop out and be able to compete. The training and development programs organized mostly hone talents and skills of a physical nature. Human beings are basically made up of two main elements, namely the spiritual element and the physical element and this element is in dire need of balanced demands. Most of them only fulfil the development or training of a purely material nature without emphasis on the spiritual aspect. While Islam always demands its people to excel in both aspects. In fact, the spiritual aspect is the most important. This is because, starting from this spiritual aspect then other branches of excellence or physical development can be born because man starts from within a human being himself (Abdul Ghani Azmi \& Hamzah, 2015). Therefore, the aspect of spiritual development must be taken into account so that the success obtained does not stray from what is written and outlined by the Qur'an and Hadith which is a permanent reference and guide to human beings of all worlds.

\section{Training and Development Definition}

This section will discuss the definition of training and development, according to some researchers. Among them are, according to Poon (2002); Yusof (2006) and Kadir (2009), training and development refers to the efforts made by an organization to provide learning facilities to employees in the organization. Training and development has the following objectives; first, instilling awareness in the individual; second, to enhance the skills of an employee in one or more areas of expertise; and third, to increase the motivation of an employee in order to carry out its work better. According Aguinis \& Kraiger (2009), training and development carried out an organization to provide its employees with the learning and skills to result in an increase in the form of knowledge, ability and attitude in their work in the period immediately and in the future.

In organizations, training is a learning process designed to change attitudes, improve knowledge and skills of workers so that their performance can be improved. Since organizations typically face a variety of low-performing employee problems, the main function of training is to try to overcome these problems. Most organizations plan training programs in the belief that training can overcome all problems related to employees in the organization (Mamat, 1996).

According to Othman (1991); training is all the efforts made by the organization to improve the ability of a person to perform his duties or play a role that has been set by the organization. Training can also be said to be a planning activity of an organization to improve 
the knowledge and social behaviour of its employees to be in line with the goals of the organization. Such activities range from simple physical skills to the formation and change of complex attitudes. However, the concept of training can be explained through the following features; first, a learning process that has specific content; second, its goals are immediate and work-oriented; third, its duration is short but prolonged; fourth, the method of its implementation formally and informally but planned; and fifth, the goal is for the selfdevelopment of employees either from a psychological or cognitive aspect. Development refers to the efforts of the organization and the efforts of individuals to improve one's ability to develop themselves in the organization. Training is more focused on preparing employees specifically for the tasks that have been assigned to them while in development programs, things delivered to a person may not be necessary for the tasks he or she undertakes at the time, but will be able to enrich an employee's knowledge and skills. Training is more current oriented and future oriented development, i.e. the knowledge and skills acquired are intended for future use.

According to Jamil (2008), training is defined as a formal and planned intervention performed by the organization aims to provide its employees with the skills, knowledge and capabilities needed to perform their duties and responsibilities effectively so that organizational goals can be achieved. Skills refer to the competencies that employees need to have to perform their assigned tasks easily and effectively. Knowledge means a basic understanding of concepts or principles related to a subject or field while ability means the ability of employees to perform the physical or mental functions required in a task.

The definitions expressed are mostly based on common or conventional perspectives. Azmi (2013) submitted that the definition of training and development from an Islamic perspective is different. He thinks training and development is a practice done after a person is hired. The main purpose of training and development in Islam is not only to train the mind but also to train the spiritual as well as the physical. Training techniques and trainee characteristics are also important in Islam such as emphasizing spiritual aspects first before doing mental and physical training. The mind cannot be trained well if the spiritual is not trained first because good spirituality will trigger good mind and physical.

Based on these definitions, it can be concluded that the definition of training and development from an Islamic perspective is any training and development that is based on Islam and spirituality without neglecting the physical aspects planned or implemented by an organization that aims to develop the personality of a person or employee. appreciate the concept of life as a servant and caliph of Allah SWT. In the context of this paper, the purpose of training and development adopted is to refer to all forms of training and development in human management that are based on Islam and spirituality without neglecting the physical aspects.

\section{Systematic Review on Training and Development in Human Management}

Training and development are among the important aspects in improving employee performance in an organization. Without training and development in managing people, negative impact can hit an organization. This is due to the emergence of problems such as inefficient workers, malpractice, misconduct, and rampant corruption. As such, the question that arises is, to what extent the emphasis given by previous researchers in examining these aspects of training and development. The results show that there are many studies that have been done related to training and development. Most of the studies conducted are studies related to training and development from a conventional perspective. Few studies touch in 
detail on training and development from an Islamic perspective. Among the key themes that have been identified are such as the basics and concepts of training and development, management and implementation of training and development, strategy and design of training and development, effectiveness of training and development, and training and development according to Islamic perspective.

\subsection{Training and Development Basic Concepts}

Among the researchers who have presented the basics and concepts of training and development are Rowe (1996); Garavan (1997); Odini (1999). Rowe (1996) has examined the basics in employee training and development and has formulated several processes in the implementation of training and development such as planning, implementation, review, and objectives of employee training and development programs in an organization. Garavan (1997) presented the concepts, differences and similarities between training, development, education and learning among employees. Odini (1999) argues that training and development can change the work environment involving employees and organizations. Based on the study of the basics and concepts of training and development by these researchers, these studies still focus on the basics and concepts of training and development in the physical aspect that is the skills and abilities of employees in their work alone and not concerned with spiritual workers.

\section{Management and Execution of The Training and Development}

In the theme of management and implementation of training and development, among the researchers who have conducted the study are Analoui (1994), Ikhlas \& Al-Homoud (1995), Al Bahar, Peterson, \& Taylor (1996), Browell (1996), Heraty (1998), Salleh (1999), Morrow (2001), Omar, Tarin, Ashjaei, Mirzoev, \& Sheikh (2007), Preston (2009), Bakri, Yoong, \& Hussin (2009), Kudus, Sidek, Hussin, \& Abu Hassan (2011), Kougias, Seremeti, \& Kalogeras (2013), Mustapha \& Mohd Shahwahid (2014) and Sabella \& Analoui (2015).

Analoui (1994) looks at the influence of coaches whose roles and responsibilities in employee training and development. Ikhlas \& Al-Homoud (1995), Al Bahar, Peterson, \& Taylor (1996), Heraty (1998), Morrow (2001), Omar, Tarin, Ashjaei, Mirzoev, \& Sheikh (2007), Kougias, Seremeti, \& Kalogeras (2013), and Sabella \& Analoui (2015) examine management in training and development practices implemented in certain countries such as Kuwait, Bahrain, Ireland, Iran, Palestine and European countries. Most of the training and development practices implemented in these countries focus on increasing the level of productivity of employees in performing the tasks assigned by the organization or institution.

In Malaysia, a study that focuses on the implementation of training and development is a study by Salleh (1999) that examines the implementation of training and employee development by local authorities in Malaysia. Browell (1996) examines the management and implementation aspects of training and employee development in an organization from a legal aspect. Preston (2009), Bakri, Yoong, \& Hussin (2009) Kudus, Sidek, Hussin, \& Abu Hassan (2011), and Mustapha \& Mohd Shahwahid (2014) have examined the relationship between individual and organizational roles with training and development practices implemented.

Analoui (1994), Mühlemeyer \& Clarke (1997), Gilleard (1998), Muhamad \& Teh (1998), AlKhayyat (1998), Horwitz (1999), Roffe (1999), Nikandrou, Brinia, \& Bereri (2009), Mayfield (2011), Dirani (2012); and Rindam, Wan Ahmad, Othman, \& Hassan (2013) are among the researchers who focus on research on training strategy and design and development. Analoui (1994), Mühlemeyer \& Clarke (1997), and Dirani (2012) state that the strategy used in 
determining training and development as a determining aspect of the success of an organization.

Gilleard (1998); Muhamad \& Teh (1998) stated that states that one of the strategies to determine the success of training and employee development is to determine the coach is a truly trained individual or group or has been recognized for his credibility. Al-Khayyat (1998) states that training and development should be evaluated to produce a training and development model that is practical and able to meet the needs of employees and organizations while Horwitz (1999); Roffe (1999), and Nikandrou, Brinia, \& Bereri (2009) submits the opinion that strategic approach, innovation and creativity in training and development can increase the effectiveness of a training and employee development.

\section{Training and Development Designs}

From the aspect of training design and development, some researchers have put forward several methods in the implementation of training and employee development. Mayfield (2011), has presented the method of assess, design, develop, implement, and evaluate (ADDIE) as one of the methods in employee training and development and Rindam, et. al. (2013) have presented the Lead program as one of the methods in employee training and development. However, there are still no researchers who study the methods in the implementation of training and development based on Islam. Most of the methods implemented focus more on physical aspects such as the ability and skills of employees in performing their duties.

\section{The effectiveness of Training and Development}

The effectiveness of training and development is one of the themes that are also the focus of researchers. Among the researchers who focused their research on the effectiveness of training and development are Suzuki (1986); Ab Rahim (1993); Bagshaw (1996); Adamson (1996); Abdul Kadir \& Ismail (1997); Burden \& Proctor (2000); Wan Sulaiman (2001); Ismail, Omar, \& Yahya (2003); Olufemi (2009); Ghosh, Joshi, Satyawadi, Mukherjee, \& Ranjan (2011); Ghosh, Satyawadi, Joshi, Ranjan, \& Singh (2012); Harris, Chung, Hutchins, \& Chiaburu (2014); Tai (2006); Ubeda-García, Marco-Lajara, Sabater-Sempere, \& García-Lillo (2013); Ellström \& Ellström (2014); Robson \& Mavin (2014).

This aspect of the effectiveness of training and development can be divided into several small themes. First, aspects of evaluating the effectiveness of training and development practices have been implemented by several researchers. Among them Suzuki (1986) who evaluated the effectiveness of training and employee development practices implemented by Japan, $A b$ Rahim (1993) has examined the effectiveness of training and development in Polytechnics Ministry of Higher Education Malaysia while Olufemi (2009) has examined the effectiveness of training and employee development in institutions banking in Nigeria. Adamson (1996) has evaluated training and development from a financial aspect. He noted that the best training and development practices are the cheapest and most economical but have the highest positive impact on employees and organizations.

Second, Abdul Kadir \& Ismail (1997); Burden \& Proctor (2000); Wan Sulaiman (2001); Ismail, Omar, \& Yahya (2003), examine the relationship between training effectiveness and development with employee performance in an organization. Ghosh et. al. (2011), Tai (2006), Ubeda-García et. al. (2013); Ellström \& Ellström, 2014 and Robson \& Mavin (2014) in turn evaluated the effectiveness of employee training and development and its relationship to employee reaction. While Ghosh et. al. (2012); Harris et. al. (2014) evaluated the effectiveness 
of employee training and development and its relationship with coach characteristics. Bagshaw (1996), examines the effectiveness of training and employee development in forming positive relationships between employees and organizations while Ubeda-García et. al. (2013), evaluated the effectiveness of employee training and development and its relationship to organizational performance. It can be concluded that, the effectiveness of training and development has been extensively studied by researchers with several small themes namely the relationship of training and development effectiveness with the financial aspects of the organization, employee and organizational performance, coaches and the relationship between employees and organizations. The results of the study also found that, the goal of most organizations is to increase the level of productivity of employees to obtain maximum material benefits. As such, in most studies, effectiveness is assessed through the profits or benefits gained by the organization and from the perspective of employees, through their skills and level of productivity in performing tasks and spiritual aspects are not a priority.

\subsection{Training and Development from Islamic Perspectives}

Training and development according to the Islamic perspective is one of the themes that are also the choice of researchers even though the number is still small. However, most of these studies are still at the conceptual stage, preliminary studies and some only evaluate conventional training and development from an Islamic perspective. Among the researchers are Ngah (2004); Akdere, Russ-Eft, \& Eft (2006); Ali \& Al-Owaihan (2008); Hashim (2009); Ali (2010); Khan, Farooq, \& Hussain (2010); Mellahi \& Budhwar (2010); Hashim (2010); Abdul Ghani Azmi (2010); Branine \& Pollard (2010); Hassi (2012); Alhyasat (2012); Khan \& Sheikh (2012); Abdullah (2012); (Alorfi, 2012); Hoque, Khan, \& Mowla (2013); Khan \& Rasheed (2014); Muis (2014); Abang Muis (2015); Muis et al (2018), Alias et al. (2019). Hassi (2012) has presented the basics and theories of training and employee development according to Islamic perspective. Next, Ali \& Al-Owaihan (2008); Hashim (2009); Ali (2010); Khan, Farooq and Hussain (2010); Mellahi \& Budhwar (2010); Branine \& Pollard (2010) have continued research on training practices and development from an Islamic perspective and its challenges in today's modern organization. Akdere, Russ-Eft \& Eft (2006) also look at the aspect of relationship with God (habl min Allah) in the implementation of training and employee development in the organization. In Malaysia, not many studies have been conducted on training and development according to the Islamic perspective. Among the studies that have been conducted are by Ngah (2004); Azmi (2010); Muis et. al. (2018) have examined the implementation of training and development practices implemented in Islamic organizations in Malaysia while Hashim (2010) has examined the relationship between organizational commitment and training and development of employees from an Islamic perspective. As such, as a result of the previous survey that has been conducted, studies on training and development in Islamic-based human management have not yet been conducted by researchers and further studies need to be conducted to look at aspects of training and development in human management through Islamic perspective.

\section{Conclusion}

For the conclusion, this paper consists of five main themes that find by the systematic reviews from the sources that listed earlier. First, training and development basic concepts, management and execution of the training and development, training and development designs, the effectiveness of training and development and, training and development from Islamic perspectives. Systematic reviews do not necessarily constitute the end of discovery. Researchers from academic, professional or the public can use existing systematic reviews to 
critique previous studies or initiate future research. Future research should shift toward the growing needs of the training and development. In conclusion, studies related to training and development have indeed been widely implemented by contemporary thinkers. Themes such as the basics and concepts of training and development, management and implementation of training and development, training and development strategy and design, effectiveness of training and development, and training and development according to Islamic perspective are among the themes that are the main focus of researchers. The results of the study found that most of the studies conducted focused on training and development that try to be used to improve the performance of employees in the organization to bring benefits to the organization and achieve organizational goals alone. Much of this study focuses on conventional training and development. There are some aspects that have not been touched upon by previous researchers. Among them are the aspects of training and development in human management from an Islamic perspective and the implementation of training and development of employees based on Islam that requires further study and research to be conducted.

\section{Acknowledgement}

The authors would like to acknowledge for the financial supports given by Fundamental Research Grant Scheme for Research Acculturation of Early Career Researchers (FRGS-RACER) from Ministry of Education Malaysia. The title of this study is Pembangunan Model Latihan bagi Institusi Dakwah Islam di Sabah (Project Code: RACER07-2019). We thank all members of the research team who have contributed to this research.

\section{Corresponding Author}

Abang Mohd. Razif Abang Muis

Centre for the Promotion of Knowledge and Language Learning, Universiti Malaysia Sabah 88400 Kota Kinabalu, Sabah, Malaysia

Email: amrazif@ums.edu.my

\section{References}

Ab Rahim, S. N. (1993). Keberkesanan kursus-kursus anjuran Unit Latihan dan Pendidikan Lanjutan terhadap staf Politeknik-politeknik Kementerian Pengajian Tinggi Malaysia. 15.

Muis, A. M. R. (2014). Kaedah pembangunan insan berteraskan Islam: Kajian kes di Kolej Universiti Antarabangsa Selangor (KUIS). Disertasi Sarjana, Universiti Sains Malaysia.

Muis, A. M. R. (2015). Pembangunan insan berteraskan Islam. Dewan Bahasa dan Pustaka.

Muis, A. M. R., Alias, M. S., Kamaruding, M., \& Mokthar, M. Z. (2018). Islamic Perspective on Human Development Management: A Philosophical Approach. International Journal of Academic Research in Business and Social Sciences, 8(4), 543-552. https://doi.org/10.6007/IJARBSS/v8-i4/4031

Azmi, A. G. I. (2010). Islamic human resource practices and organizational performance: A preliminary finding of Islamic organizations in Malaysia. Journal of Global Business and Economics, 1(1), 27-42.

Azmi, A. G. I. (2013). Amalan pengurusan sumber manusia mengikut al-Quran dan hadis. Penerbit Universiti Sains Islam Malaysia (USIM).

Azmi, A. G. I., \& Hamzah, N. (2015). Human resource management practices in the era of Khulafa al-Rashidin (11-40 AH/ 632-661 AD). Jurnal Usuluddin, 42(4), 147-174.

Abdul Kadir, A. L., \& Ismail, M. (1997). Hubungan keberkesanan latihan dengan prestasi kerja. 
Pertanika, 5(2), 73-82.

Abdullah, M. F. (2012). The role of Islam in human capital development: A juristic analysis. Humanomics, 28(1), 64-75.

Adamson, P. (1996). The training and development audit evolves: Is your training and development budget wasted? Journal of European Industrial Training, 20(5), 3-12. https://doi.org/http://dx.doi.org/10.1108/03090599610119674

Aguinis, H., \& Kraiger, K. (2009). Benefits of training and development for individuals and teams, organizations, and society. Annual Review of Psychology, 60, 451-474. https://doi.org/http://dx.doi.org/10.0.4.122/annurev.psych.60.110707

Akdere, M., Russ-Eft, D., \& Eft, N. (2006). The Islamic worldview of adult learning in the workplace: Surrendering to God. Advances in Developing Human Resources, 8(3), 355363. https://doi.org/http://dx.doi.org/10.1177/1523422306288428

Al-Khayyat, R. (1998). Training And development needs assessment: a practical model for partner institutes. Journal of European Industrial Training, 22(1), 18-27. https://doi.org/10.1108/03090599810197658

Al Bahar, A. A., Peterson, S. E., \& Taylor, W. G. K. (1996). Managing training and development in Bahrain: The influence of culture. Journal of Managerial Psychology, 11(5), 26-32. https://doi.org/http://dx.doi.org/10.1108/02683949610124799

Alhyasat, K. M. K. (2012). The role of Islamic work ethics in developing organizational citizenship behavior at the Jordanian Press Foundations. Journal of Islamic Marketing, 3(2), 139-154.

Ali, A. J. (2010). Islamic challenges to human resources in modern organizations. Personnel Review, 39(6), 692-711. https://doi.org/http://dx.doi.org/10.1108/00483481011075567

Ali, A. J., \& Al-Owaihan, A. (2008). Islamic work ethic: A critical review. Cross Cultural Management: An International Journal, 15(1), 5-19.

https://doi.org/http://dx.doi.org/10.1108/13527600810848791

Alorfi, S. (2012). Human resource management from an Islamic perspective. Journal of Islamic and Human Advanced Research, 2, 86-92.

Aminuddin, M. (1994). Pengurusan sumber manusia. Dewan Bahasa dan Pustaka.

Analoui, F. (1994). Training and development: the role of trainers. Journal of Management Development, 13(9), 61-72. https://doi.org/10.1108/02621719410072107

Bagshaw, M. (1996). Creating employability: How can training and development square the circle between individual and corporate interest? Industrial and Commercial Training, 28(1), 16-18. https://doi.org/http://dx.doi.org/10.1108/00197859610105431

Bakri, N., Yoong, S. K., \& Hussin, H. (2009). Hubungan antara Peranan Individu dan Organisasi dengan Amalan Pembangunan Kerjaya. Journal of Human Capital Development, 2(1), 1324.

Branine, M., \& Pollard, D. (2010). Human resource management with Islamic management principles: A dialectic for a reverse diffusion in management. Personnel Review, 39(6), 712-727.

Browell, S. (1996). Training and development specialists and the law. Journal of European Industrial Training, 20(2), 25-32. https://doi.org/http://dx.doi.org/10.1108/03090599610110448

Burden, R., \& Proctor, T. (2000). Creating a sustainable competitive advantage through training. Team Performance Management, 6(5/6), 90-97.

https://doi.org/http://dx.doi.org/10.1108/13527590010348200 
Dirani, K. M. (2012). Professional training as a strategy for staff development: A study in training transfer in the Lebanese context. European Journal of Training and Development, 36(2/3), 158-178. https://doi.org/10.1108/03090591211204698

Ellström, E., \& Ellström, P.-E. (2014). Learning outcomes of a work-based training programme: The significance of managerial support. European Journal of Training and Development, 38(3), 2. https://doi.org/http://dx.doi.org/10.1108/EJTD-09-2013-0103

Garavan, T. (1997). The learning organization: A review and evaluation. The Learning Organization, 4, 18-29.

Ghosh, P., Joshi, J. P., Satyawadi, R., Mukherjee, U., \& Ranjan, R. (2011). Evaluating effectiveness of a training programme with trainee reaction. Industrial and Commercial Training, 43(4), 247-255. https://doi.org/http://dx.doi.org/10.1108/00197851111137861

Ghosh, P., Satyawadi, R., Joshi, J. P., Ranjan, R., \& Singh, P. (2012). Towards more effective training programmes: A study of trainer attributes. Industrial and Commercial Training, 44(4), 194-202. https://doi.org/http://dx.doi.org/10.1108/00197851211231469

Gilleard, J. (1998). Trainers need training too. Empowerment in Organizations, 6(1), 19-26. https://doi.org/http://dx.doi.org/10.1108/14634449810370051

Harris, T. B., Chung, W., Hutchins, H. M., \& Chiaburu, D. S. (2014). Do trainer style and learner orientation predict training outcomes? Journal of Workplace Learning, 26(5), 331-344. https://doi.org/http://dx.doi.org/10.1108/JWL-05-2013-0031

Hashim, J. (2009). Islamic revival in human resource management practices among selected Islamic organisations in Malaysia. International Journal of Islamic and Middle Eastern Finance and Management, 2(3), 251-267.

Hashim, J. (2010). Human resource management practices on organizational commitment: The Islamic perspective. Personnel Review, 39(6), 785-799.

Hassi, A. (2012). Islamic perspectives on training and professional development. Journal of Management Development, 31(10), 1035-1045. https://doi.org/http://dx.doi.org/10.1108/02621711211281816

Heraty, N. (1998). Training and development in the Irish context: Responding to the competitiveness agenda? Journal of European Industrial Training, 22(4), 190-204.

Hoque, N., Khan, M. A., \& Mowla, M. M. (2013). Organisational culture: Features and framework from Islamic perspective. Humanomics, 29(3), 202-219.

Horwitz, F. M. (1999). The emergence of strategic training and development: The current state of play. Journal of European Industrial Training, 23(4), 180-190.

Ikhlas, A. A., \& Al-Homoud, M. (1995). A survey of management training and development practices in the state of Kuwait. Journal of Management Development, 14(3), 14-25. https://doi.org/http://dx.doi.org/10.1108/02621719510078939

Ismail, Z., Omar, A., \& Yahya, K. K. (2003). Pekerja bermasalah: Hubungan antara persepsi masalah, tindakan dan kesan terhadap prestasi. Utara Management Review, 4(1), 6784.

Jamil, R. (2008). Analisis keperluan latihan teori dan praktis. Penerbit Universiti Teknologi Malaysia (UTM).

Kadir, M. B. A. (2009). Learning organisation: Membangun budaya belajar dalam organisasi. PTS Professional Publishing Sdn. Bhd.

Khan, A. S., \& Rasheed, F. (2014). Human resource management practices and project success, a moderating role of Islamic work ethics in Pakistani project-based organizations. International Journal of Project Management, 33(2), 11. 
https://doi.org/http://dx.doi.org/10.1016/j.ijproman.2014.08.006

Khan, B., Farooq, A., \& Hussain, Z. (2010). Human resource management: An Islamic perspective. Asia-Pacific Journal of Business Administration, 2(1), 17-34. https://doi.org/http://dx.doi.org/10.1108/17574321011037558

Khan, M. B., \& Sheikh, N. N. (2012). Human resource development, motivation and Islam. Journal of Management Development, 31(10), 1021-1034.

Kougias, I., Seremeti, L., \& Kalogeras, D. (2013). Mobility of eastern European citizens: training and development. European Journal of Training and Development, 37(8), 766-778.

Kudus, N., Sidek, S., Hussin, S., \& Abu Hassan, M. (2011). Learning Organization Practices as Human Resource Development for Transformational Change at UTeM. Journal of Human Capital Development, 4(2), 117-128.

Shah, M. I. (2002). Pengenalan psikologi industri dan organisasi. Penerbit Universiti Teknologi Malaysia (UTM).

Mamat, I. (1996). Reka bentuk dan pengurusan latihan: Konsep dan amalan. Dewan Bahasa dan Pustaka.

Mayfield, M. (2011). Creating training and development programs: Using the ADDIE method. Development and Learning in Organizations, 25(3), 19-22. https://doi.org/http://dx.doi.org/10.1108/14777281

Mellahi, K., \& Budhwar, P. S. (2010). Introduction: Islam and human resource management. Personnel Review, 39(6), 685-691.

Morrow, T. (2001). Training and Development in The Northern Ireland Clothing Industry. Journal of European Industrial Training, 25(2), 80-89.

https://doi.org/10.1108/EUM0000000005439

Muhamad, M., \& Teh, S. (1998). Latihan sebagai strategi pembangunan mampan: Satu kajian kes. Pertanika, 6(1), 51-61.

Mühlemeyer, P., \& Clarke, M. (1997). The Competitive Factor: Training and Development as A Strategic Management Task. Journal of Workplace Learning, 9(1), 4-11. https://doi.org/10.1108/13665629710160395

Mustapha, N. H., \& Mohd Shahwahid, F. (2014). Hubungan antara amalan pengurusan sumber manusia dengan niat kakitangan akademik untuk terus kekal di universiti swasta. 2nd International Conference on Social Sciences Research, 2014(June), 885-897.

Ngah, M. Y. (2004). Latihan dalam pembangunan kerjaya dari perspektif pengurusan Islam: Kajian di Institut Latihan Kakitangan MARA (ILHAM), Majlis Amanah Rakyat, Kuala Lumpur. Masters Dissertation, Akademi Pengajian Islam, Universiti Malaya.

Nikandrou, I., Brinia, V., \& Bereri, E. (2009). Trainee perceptions of training transfer: An empirical analysis. Journal of European Industrial Training, 33(3), 255-270. https://doi.org/10.1108/03090590910950604

Odini, C. (1999). Training and Development of Skills in A Changing Information Environment. Library Management, 20(2), 100-104. https://doi.org/10.1108/01435129910251566

Olufemi, A. J. (2009). Human capital development practices and organizational effectiveness: A focus on the contemporary Nigerian banking industry. Pakistan Journal of Social Sciences, 6(4), 194-199.

Omar, M., Tarin, E., Ashjaei, K., Mirzoev, T., \& Sheikh, M. R. (2007). In-country Capacity Development of a Training Institute: An Iranian Experience. Journal of Health Organization and Management, 21(6), 519-532.

https://doi.org/10.1108/14777260710834319

Othman, R. (1991). Pengurusan personel dan perancangan guna tenaga. Dewan Bahasa dan 
Pustaka.

Poon, J. M. L. (2002). Pengurusan sumber manusia. Dewan Bahasa dan Pustaka.

Preston, A. (2009). Balancing Training and Development Programmes for Your Team. Industrial and Commercial Training, 41(3), 142-145.

https://doi.org/10.1108/00197850910950934

Rindam, M., Wan Ahmad, W. F., Othman, M. H., \& Hassan, A. (2013). Pimpin sebagai kaedah melestarikan modal insan kakitangan universiti. Journal of Human Capital Development, 6(1), 111-132.

Robson, F., \& Mavin, S. (2014). Evaluating training and development in UK universities: Staff perceptions. European Journal of Training and Development, 38(6), 553-569.

Roffe, I. (1999). Innovation and creativity in organisations: a review of the implications for training and development. Journal of European Industrial Training, 23(4), 224-241. https://doi.org/10.1108/03090599910272103

Rowe, C. (1996). Management training and development: Revisiting the basic issues. Training, 28(4), 17-23.

Sabella, A. R., \& Analoui, F. (2015). Managerial Training And Development In Telecommunication Organizations In Palestine. Journal of Management Development, 34(6), 685-703.

Salleh, Z. (1999). Program latihan pembangunan sumber manusia: Kajian amalan latihan bagi Kumpulan B dan Sokongan C di Penguasa Tempatan. Universiti Putra Malaysia.

Suzuki, N. (1986). Problems and prospects of Japanese companies training programmes. Asia Pacific Journal of Management, 3(2), 110-120.

Tai, W.-T. (2006). Effects of training framing, general self-efficacy and training motivation on trainees training effectiveness. Personnel Review, 35(1), 51-65.

Ubeda-García, M., Marco-Lajara, B., Sabater-Sempere, V., \& García-Lillo, F. (2013). Does training influence organisational performance?: Analysis of the Spanish hotel sector. In European Journal of Training and Development (Vol. 37, Issue 4).

Wan Sulaiman, W. I. (2001). Pembangunan personelia dalam aspek latihan dan pembangunan: Antara realiti dan formaliti keberkesanan tugas. Jurnal Komunikasi, 17(6), 81-118.

Yusof, A. A. (2006). Pengurusan sumber manusia: Konsep, isu dan pelaksanaan (3rd ed.). Prentice Hall, Pearson Malaysia Sdn. Bhd. 